Manuscript.

Published version:

Journal of Peptide Science 2016; 22:552-560

DOI: 10.1002/psc.2904 


\title{
Synthesis, characterisation and systematic comparison of FITC-labelled GnRH-I, -II and -III analogues on various tumour cells
}

\author{
József Murányi ${ }^{\text {a,b* }}$, Pál Gyulavári ${ }^{\text {a }}$, Attila Varga ${ }^{\text {a }}$, Györgyi Bökönyi ${ }^{\text {a }}$, \\ Henriette Tanai ${ }^{\text {a }}$, Tibor Vántus ${ }^{b}$, Domonkos Pap ${ }^{c}$, Krisztina Ludányi $^{\mathrm{d}}$, \\ Gábor Mezö $^{\mathrm{e}}$ and György Kéri ${ }^{\mathrm{a}, \mathrm{b}}$
}

${ }^{a}$ MTA-SE Pathobiochemistry Research Group, Tüzoltó St. 37-47, H1094 Budapest, Hungary

${ }^{b}$ Department of Medical Chemistry, Molecular Biology and Pathobiochemistry, Semmelweis University, Tüzoltó St. 37-47, H1094 Budapest, Hungary

${ }^{c} 1$ st Department of Pediatrics, Semmelweis University, Bókay János St. 53-54, H1083, Budapest, Hungary

${ }^{d}$ Department of Pharmaceutics, Semmelweis University, Högyes Endre St. 7, H1092 Budapest, Hungary

${ }^{e}$ MTA-ELTE Research Group of Peptide Chemistry, Hungarian Academy of Sciences, Eötvös L. University, Pázmány Péter sétány 1/A, H1518 Budapest, Hungary

\footnotetext{
*Correspondence to: József Murányi, Department of Medical Chemistry, Molecular Biology and Pathobiochemistry, Semmelweis University, Tüzoltó St. 37-47, H1094 Budapest, Hungary.E-mail: jozsefmuranyi84@gmail.com
}

\section{Abstract}


Targeted tumour therapy is in the focus of recent cancer research. GnRH analogues are able to deliver anticancer agents selectively into tumour cells which highly express GnRH receptors. However, the effectiveness of different analogues as targeting moiety in drug delivery systems is rarely compared and the investigated types of cancers are also limited. Therefore, we prepared selectively labelled, fluorescent derivatives of GnRH-I, -II, and -III analogues which successfully used for drug targeting. In this manuscript we investigated these analogues solubility, stability, passive membrane permeability and compared their cellular uptake by various cancer cells.

We found that these labelled GnRH conjugates provide great detectability, without undesired cytotoxicity and passive membrane permeability. The introduced experiments with these conjugates proved their reliable tracking, quantification and comparison. Cellular uptake efficiency was studied on human breast, colon, pancreas and prostate cancer cells (MCF-7, HT-29, BxPC-3, LNCaP) and on dog kidney cells (MDCK). Each of the three conjugates were taken up by GnRH-I receptor expressing cells, but the different cells preferred different analogues. Furthermore, we demonstrated for the first time the high cell surface expression of GnRH-I receptors and the effective cellular uptake of GnRH analogues on human pharynx tumour (Detroit-562) cells.

In summary, our presented results detail that the introduced conjugates could be innovative tools for the examination of the GnRH based drug delivery systems on various cells and offer novel information about these peptides.

Keywords: targeted therapy, GnRH, LHRH, FITC, conjugate, pharynx tumour, Detroit-562

\section{Abbreviations}
Alloc
Allyloxycarbonyl 

morpholino-carbenium hexafluorophosphate

DCM

DMEM

DMF

DMSO

FACS

FITC

Fmoc

GnRH

GnRH-R

GnRH-I-R

ivDde

MDCK

MFI

NMM

PAMPA

PBS

RPMI

TFA

TIPS
Dichloromethane

Dulbecco's Modified Eagle's medium

$\mathrm{N}, \mathrm{N}$-Dimethylformamide

Dimethyl sulfoxide

Fluorescence Activated Cell Sorting

Fluorescein isothiocyanate

Fluorenylmethyloxycarbonyl

Gonadotropin-releasing hormone

Gonadotropin-releasing hormone receptor

Type I gonadotropin-releasing hormone receptor

1-(4,4-Dimethyl-2,6-dioxocyclohex-1-ylidene)-3-methylbutyl

Madin-Darby Canine Kidney

Median Fluorescence Intensity

4-Methylmorpholine

Parallel Artificial Membrane Permeability Assay

Phosphate-buffered saline

Roswell Park Memorial Institute

Trifluoroacetic acid

Triisopropylsilane

\section{Introduction}

Cancer is the second leading cause of death in the developed countries [1]. Among treatment options for cancer one of the most promising and developing procedure is the targeted 
chemotherapy, based on the tumour selective or over-expressed receptors. The high expression of gonadotropin releasing hormone receptor (also called luteinizing hormone releasing hormone receptor) has been identified in many types of cancer [2-4]. Therefore the natural and artificial ligands of GnRH receptors are extensively studied as tumour targeting systems [5-8].

Human pituitary GnRH-R has crucial role in the control of the reproductive system, and it is a well-known molecular target in the treatment of reproduction-related diseases [9]. GnRH analogues are widely and successfully used for the treatment of different hormone related pathologies based on their ability to suppress the hypothalamic-pituitary-gonadal axis [10].

GnRH receptors are also expressed in number of cancer tissues, either related or unrelated to the reproductive system [11]. It was indicated that $\mathrm{GnRH}$ and its receptors are a part of an autocrine/paracrine regulatory system of cell proliferation in malignant tumours [11-13]. In addition, the proliferation can be inhibited by agonist or antagonist analogues of $\mathrm{GnRH}$ in a dose and time dependent manner both in vitro and in vivo $[12,14]$. Furthermore, GnRH derivatives can be used as homing devices to deliver anticancer drugs into cancer cells expressing GnRH receptors [15]. Cytotoxic drug - GnRH conjugates could dramatically improve the antitumour efficiency of $\mathrm{GnRH}$ analogues and represent a very promising therapeutic approach for certain tumours. Schally and co-workers developed potent GnRH-

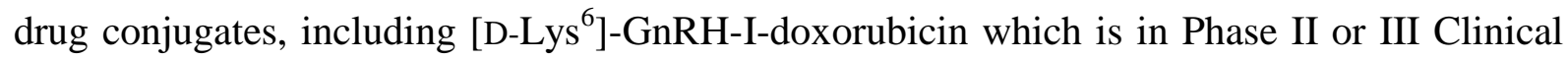
Trial for several types of cancer [8].

Besides GnRH-I, a second native isoform of GnRH (first isolated from chicken (Gallus gallus domesticus) [16]) was identified in humans [17]. The GnRH-II receptor was revealed in various species including nonhuman primates, but the existence of GnRH-II receptor in the human organism is still controversial [18]. Fister and co-workers reported that GnRH-II 
antagonists are able to bind to the GnRH-I receptor (GnRH-I-R), and their binding affinity are similar to the GnRH-I antagonist Cetrorelix [19]. Furthermore, Montagnani et al. reported that the effect of GnRH-II was mediated by GnRH-I-R on prostate cancer cells [20]. GnRH-II had strong antiproliferative effect and induced apoptosis in endometrial, ovarian, breast and prostate cancer cell lines as well [18-21]. Gründker et al. reported that on the human ovarian cancer cell line SK-OV-3, which does not express GnRH-I-R, the GnRH-I antagonist Cetrorelix and GnRH-II had strong antiproliferative effect [22]. These results suggested that the antiproliferative effect of GnRH-II in endometrial and ovarian cancer cells were not mediated through the GnRH-I-R [22]. Therefore, the GnRH-I-R seems not to be the only target for GnRH-II agonists on certain cancer cells [18]. Besides, the cytotoxic conjugates of [D-Lys ${ }^{6}$ ]-GnRH-II were also described to be effective antitumour agents [23].

A third isoform of GnRH was isolated from sea lamprey (Petromyzon marinus) [24]. Lamprey GnRH-III binds to both GnRH-I and GnRH-II receptors but with lower efficacy than their native ligands [25]. Therefore, it is a weak GnRH agonist which has insignificant endocrine effect in mammals. In addition it can recognize not only the high-, but also the lowaffinity binding sites of GnRH receptors on cancer cells [25]. In experimental setups, GnRHIII significantly suppressed the proliferation of human cancer cells which overexpress GnRH$\mathrm{R}$ [26]. Therefore, also daunorubicin containing GnRH-III conjugates were synthesized and investigated in vitro and in vivo [27-29]. These conjugates were well tolerated and had significant antitumour effect on colon carcinoma-bearing mice [29]. On castration-resistant prostate cancer cells GnRH-III-daunorubicin conjugates inhibited tumour cell proliferation and exerted their antitumour effect through the activation of GnRH-I-R [28]. Based on these observations GnRH-III-based peptides are considered promising targeting moieties for the preparation of anticancer drug delivery systems. 
Although hundreds of publications has been reported about $\mathrm{GnRH}$ and $\mathrm{GnRH}$ conjugates since it was discovered [30], there are only a few experiments with fluorescently labelled GnRH derivatives [31]. The variety of the tested cell lines has been also limited yet, and the results coming out from different studies are usually not comparable due to the different experimental parameters.

Our idea was that benefits of fluorescently-labelled $\mathrm{GnRH}$ analogues could contribute to the development of novel tumour targeting GnRH-drug conjugates, besides could help to identify new therapeutic targets and offer novel information about these peptides. Indeed, selectively labelled peptides have excellent tracking properties and allow their reliable quantification. Quantifying the uptake of these analogues may predict the adequacy of a given cancer culture for GnRH targeted therapy.

Based on these considerations we selected three effective GnRH analogues, which successfully used for drug delivery ([D-Lys $\left.{ }^{6}\right]-G n R H-I,\left[D-L y s{ }^{6}\right]-G n R H-I I$ and GnRH-III) and selectively labelled them with FITC. In the present manuscript the syntheses of [DLys $^{6}\left(\right.$ FITC)]-GnRH-I, [D-Lys ${ }^{6}$ (FITC)]-GnRH-II and [Lys ${ }^{8}($ FITC)]-GnRH-III were described and their characterization, solubility, stability, cellular permeability, cytotoxicity and cellular uptake properties were studied. To demonstrate the usability of these conjugates, we tested them on GnRH-I-R expressing LNCaP (prostate), MCF-7 (breast), BxPC-3 (pancreas) and HT-29 (colon) tumour cell lines [18,32-34], and involved a previously not investigated pharynx tumour cell line, the Detroit-562 into the experiments. We investigated the presence of the GnRH-I-R on the featured pharynx tumour and evaluated its susceptibility for GnRH targeted therapy.

\section{Materials and Methods}




\section{Synthesis of FITC labelled GnRH conjugates}

All amino acid derivatives and reagents were purchased from Sigma-Aldrich Ltd. (Budapest, Hungary). The solvents (acetonitrile, ethanol, methanol, pyridine, diethyl-ether, DCM, DMF) were purchased from Reanal Ltd. (Budapest, Hungary). All reagents and solvents were reagent grade or the highest available purity.

GnRH peptides were synthesized manually on H-Rink Amide ChemMatrix ${ }^{\circledR}$ resin using standard Fmoc strategy. The following amino acid derivatives were applied: Fmoc-Gly-OH, Fmoc-Pro-OH, Fmoc-Arg(Pbf)-OH, Fmoc-Leu-OH, Fmoc-D-Lys(Alloc)-OH, FmocTyr(tBu)-OH, Fmoc-Ser(tBu)-OH, Fmoc-Trp(Boc)-OH, Fmoc His(Trt)-OH, FmocLys(ivDde)-OH, Fmoc-Asp(OtBu)-OH. Pyroglutamic acide (pGlu) was attached to the Nterminus of the peptide without any protection. All couplings employed three equivalents of amino acid derivate, with COMU and NMM at room temperature, for 20 min. Coupling involved minimal preactivation times. The Fmoc group was removed with $20 \%$ piperidine in DMF.

The Alloc protecting group was removed in DCM by using tetrakis(triphenylphosphine)palladium(0) and phenylsilane under inert atmosphere. After deprotection, sodium $N, N$-diethyldithiocarbamate in DMF was used for the removal of palladium. The ivDde protecting group was cleaved with DMF containing $2 \%$ hydrazine hydrate. For fluorescent labelling the free $\varepsilon$-amino groups of Lys or D-Lys residues 1.1 equivalent of FITC was dissolved in a mixture of pyridine/DMF/DCM (12:7:5 ratio) and the solution was added to the resin. The conjugations were carried out overnight under inert atmosphere. The FITC labelled peptides were cleaved from the resins with TFA/phenol/water/thioanisole/TIPS (82.5:5:5:5:2.5 ratio) mixture for 2 hours at room temperature. The filtrates were precipitated in cold diethyl ether, the yellow precipitates were 
filtered and dried under vacuum to give the crude peptide conjugate. Crude peptide conjugates were purified by semi-preparative RP-HPLC, and the pure compounds were characterized by analytical RP-HPLC and ESI-mass spectrometry.

\section{High performance liquid chromatography}

Analytical and preparative RP-HPLC were performed on a Jasco HPLC system (ABL\&EJASCO Hungary Ltd., Budapest, Hungary). The crude products were purified on a Phenomenex Gemini C18 column $(150 \mathrm{~mm} / 21.4 \mathrm{~mm}, 5 \mu \mathrm{m})$. For the purification, gradient elution $(0 \min 0 \% \mathrm{~B}, 5 \mathrm{~min} 20 \% \mathrm{~B}$, and $50 \mathrm{~min} 40 \% \mathrm{~B})$ of eluent $\mathrm{A}(0.1 \%$ TFA in water $)$ and eluent B (acetonitrile) was used at a flow rate of $10 \mathrm{~mL} / \mathrm{min}$.

The purity, aqueous solubility, stability, and permeability experiments of the GnRH peptides were measured by analytical HPLC, using Technokroma ${ }^{\circledR}$ Mediterranea Sea C18 column (50 $\mathrm{mm} / 4.0 \mathrm{~mm}, 3 \mu \mathrm{m})$. Linear gradient elution $(0 \min 0 \%, 12 \mathrm{~min} 50 \% \mathrm{~B})$ of eluent $\mathrm{A}(0.1 \%$ TFA in water) with eluent $B$ (acetonitrile) was used at a flow rate of $1 \mathrm{~mL} / \mathrm{min}$. Peaks were detected by UV detector at $\lambda=220 \mathrm{~nm}$.

\section{Mass spectrometry}

Mass spectrometric analyses were carried out on a Waters Q-TOF Premier mass spectrometer (Waters Ltd., Budapest, Hungary). Electrospray ion source (ESI/MS) was used to perform MS measurements in positive ion mode in a range of 100-1800 Da. Samples were dissolved in acetonitrile/water (1:2 ratio) containing $0.1 \%$ TFA and introduced into the instrument. The ESI-MS conditions are detailed in the Supporting Information.

\section{Solubility experiment}


Solubility of FITC-GnRH conjugates was measured in PBS (pH: 7.4, without $\mathrm{Ca}^{2+}$ and $\mathrm{Mg}^{2+}$, Lonza Group Ltd. Basel, Switzerland). 10 mM DMSO stock solutions were diluted to $200 \mu \mathrm{M}$ in PBS (2\% final DMSO concentration). Samples were incubated for 24 hours at $25^{\circ} \mathrm{C}$ and centrifuged them for 30 minutes at $13.000 \mathrm{rpm}$. Supernatants were measured by HPLC-UV. External standard method was used to construct calibration curves and quantify the concentrations in supernatants. Each experiment was repeated four times.

\section{Stability experiment}

$10 \mathrm{mM}$ DMSO stock solutions were diluted to $40 \mu \mathrm{M}$ in cell culture medium (RPMI). RPMI solutions incubated for 24 hours at $37^{\circ} \mathrm{C}$. The stability of the compounds was monitored by HPLC-UV.

\section{Cell cultures}

NIH/3T3 (mouse fibroblast), LNCaP (prostate), MCF-7 (breast), BxPC-3 (pancreas), HT-29 (colon) and Detroit-562 (pharynx) cell lines were obtained from American Type Culture Collection (Rockville, MD U.S). MDCK (Madin-Darby canine kidney) wild type cell line was provided by Alfred Schinkel (Netherlands Cancer Institute, Amsterdam, The Netherlands). Cell lines maintained in the ATCC $^{\circledR}$ recommended mediums (Lonza Group Ltd., Basel, Switzerland), supplemented with 10\% (v/v) fetal bovine serum (Lonza Group Ltd.) and antibiotics (MycoZap ${ }^{\mathrm{TM}}$ Plus-CL, Lonza Group Ltd.) in a humidified, 5\% $\mathrm{CO}_{2}$ atmosphere incubator at $37^{\circ} \mathrm{C}$.

\section{Parallel artificial membrane permeability assay}

BD Gentest ${ }^{\mathrm{TM}}$ Pre-Coated PAMPA plate system was gifted by Vichem Chemie Ltd. (Budapest, Hungary). $10 \mathrm{mM}$ DMSO stock solutions were diluted to $40 \mu \mathrm{M}$ in PBS and 
loaded into the donor plate. The assembly was incubated in a plate shaker (BioSan ThermoShaker PST-60HL, BioSan, Riga, Latvia) at $250 \mathrm{rpm}$ for $5 \mathrm{~h}$ at $25^{\circ} \mathrm{C}$. Concentrations were determined by UV-VIS spectroscopy (BioTek Synergy 2 Multi-Mode Reader, BioTek U.S, Winooski, VT U.S). Each assay was repeated twice. The calculation formulas are described in the Supporting Information.

\section{MDCK permeability assay}

Costar ${ }^{\circledR}$ Transwell ${ }^{\circledR}$ Permeable Support 12 well plates $(12 \mathrm{~mm}$ insert, $0.4 \mu \mathrm{m}$ polyester membrane) were obtained from Zenon Bio Ltd. (Szeged, Hungary). MDCK cells seeded onto the insert membranes at a density of about $10^{5}$ cells/insert (in $0.5 \mathrm{~mL}$ medium). After growing for 4 days, the confluence of the cell monolayers were confirmed by microscope and measurement of transepithelial electrical resistance (EVOM2, Epithelial Voltohmmeter for TEER, World Precision Instruments, FL U.S) $10 \mathrm{mM}$ stock solutions of test compounds were prepared in DMSO and diluted with buffer solution to $10 \mu \mathrm{M}$ before transport experiments. The plates were incubated in a plate shaker (BioSan Thermo-Shaker PST-60HL), at $250 \mathrm{rpm}$ for $60 \mathrm{~min}$ at $37{ }^{\circ} \mathrm{C}$. Aliquots were collected from the chambers and the concentration was quantified by HPLC-UV. Each experiment was repeated two times.

\section{Cytotoxicity assay}

Reagents were purchased from Sigma-Aldrich Ltd. NIH/3T3 cells were seeded into 96 well plates at a density of $10^{4}$ cells/well and were treated with the compounds for 24 hours at 40 $\mu \mathrm{M}$ in complete medium. After treatment, medium was removed and $50 \mu \mathrm{L}$ PBS containing 5 $\mathrm{mg} / \mathrm{mL}$ [3-(4,5-dimethylthiaziazol-2-yl)-2,5-diphenyl-2H-tetrazolium bromide] (MTT) was added to the wells and cells were incubated for 2 hours in $37^{\circ} \mathrm{C}$. The produced tetrazolium crystals were dissolved in isopropanol containing $10 \%$ (v/v) Triton X-100 and 1\% (v/v) $0.1 \mathrm{~N}$ 
HCl. Absorbance was measured at $570 \mathrm{~nm}$ and $690 \mathrm{~nm}$ (BioTek, Synergy 2 Multi-Mode Reader). The $690 \mathrm{~nm}$ data was subtracted from the $570 \mathrm{~nm}$ for each well. Each experiment was repeated three times.

\section{Western blot analysis}

Cells were washed twice with ice-cold PBS and lysed in radioimmunoprecipitation assay (RIPA) buffer (50 mM Tris ( $\mathrm{pH} 7.4), 150 \mathrm{mM} \mathrm{NaCl}, 1 \%(\mathrm{v} / \mathrm{v}) \mathrm{NP}-40,0.5 \%$ (m/v) sodiumdeoxycholate, $0.1 \%(\mathrm{~m} / \mathrm{v})$ sodium dodecyl sulfate, $2 \mathrm{mM}$ EDTA, $2 \mathrm{mM}$ EGTA) complemented with $50 \mathrm{mM} \mathrm{NaF}, 1 \mathrm{mM}$ dithiothreitol, $1 \mathrm{mM}$ sodium-ortovanadate (reagents were obtained from Sigma Aldrich Ltd.) and protease inhibitor cocktail (Calbiochem ${ }^{\circledR}$ Cat. No.:539134) for 30 minutes on ice. Lysates were centrifuged with $10000 \mathrm{~g}$ at $4^{\circ} \mathrm{C}$ for 15 minutes. Equal amounts of protein $(40 \mu \mathrm{g})$ were subjected to SDS-PAGE and electrotransferred to polyvinylidene-difluoride (PVDF) membranes (Bio-Rad Ltd., Budapest, Hungary). Membranes were probed with GnRH-I-R specific primary antibody (Proteintech ${ }^{\mathrm{TM}}$, Catalog number: 19950-1-AP, Rosemont, IL U.S) and $\alpha$-tubulin primary antibody (Sigma Aldrich Ltd.) at $4^{\circ} \mathrm{C}$ overnight, then with horse radish peroxidase (HRP) conjugated secondary antibody (Cell Signaling Technology Inc., Danvers, MA U.S) for $1 \mathrm{~h}$ at room temperature. Bands were visualized by Enhanced Chemiluminescence (ECL) detection system (Western Lightning Plus-ECL, PerkinElmer, Waltham, MA U.S). Each experiment was repeated three times.

\section{Confocal laser scanning microscopy}

Cells were seeded on Ibidi $_{\circledast} \mu$-Slide 8 Well microscopic slides (Zenon Bio Ltd., Szeged, Hungary) in complete medium and let to adhere overnight. At the immunocytochemistry experiments, cells were fixed with $4 \%$ paraformaldehyde, washed with PBS, incubated with a 
primary antibody specific for GnRH-I receptor for 1 hour Proteintech $^{\mathrm{TM}}$, Catalog number: 19950-1-AP), then cells were washed with PBS again and incubated with a Alexa Fluor 546 conjugated secondary antibody (Catalog number: A-11035, Thermo Fisher Scientific, Waltham, MA U.S) for 1 hour. Draq5 ${ }^{\mathrm{TM}}$ (Thermo Fisher Scientific) fluorescent probe solution was added to the cells, then they were incubated for 10 min, washed with PBS and mounted with mounting media afterwards.

At the uptake experiments of GnRH conjugates, cells were treated with $10 \mu \mathrm{M}$ conjugates and incubated for $5 \mathrm{~h}$ at $37^{\circ} \mathrm{C}$. Treatment medium was removed, the cells were washed with PBS and fixed with $4 \%$ formaldehyde. Cells were washed with PBS followed by adding Draq5 $5^{\mathrm{TM}}$ and they were incubated for 10 min, washed with PBS and mounted with mounting media afterwards.

Images of cells were acquired under an oil immersion objective with confocal laser microscope (Zeiss Confocal LSM 710, Carl Zeiss AG, Oberkochen, Germany)

\section{Flow cytometry analysis}

Approximately $10^{5}$ cells were seeded per well to 24 well plates in complete medium and let to adhere overnight. Next day cells were treated with conjugates or vehicle (DMSO) at the indicated concentrations in full medium and incubated for $1 \mathrm{~h}$ or $5 \mathrm{~h}$. After incubation supernatant was discarded, trypsin was added for $10 \mathrm{~min}$, at $37^{\circ} \mathrm{C}$. Cells were pelleted $(250 \mathrm{~g}$, 4 min, RT) in FACS tubes, resuspended in $300 \mu \mathrm{L}$ PBS and kept at $4{ }^{\circ} \mathrm{C}$ for the rest of the experiment. The fluorescence intensity of the conjugate-stained cells was analysed by a FACS Calibur flow cytometer (BD Biosciences, San Jose, CA) using the FL1 channel. Data were evaluated by CellQuest Pro software (BD Biosciences). The total uptake (relative MFI values, based on DMSO control) of conjugates were calculated at $1 \mu \mathrm{M}$, after 1 hour and 5 hours incubations. The uptake was calculated at $1 \mu \mathrm{M}$ and $10 \mu \mathrm{M}$, between the 1 hour and 5 hours 
incubations, as well. Calculation formulas are described in the Supporting Information. Each experiment was repeated three times.

\section{Results and Discussion}

GnRH analogues and their cytotoxic conjugates were reported as effective antitumour agents. Numerous studies were published about GnRH based tumour targeting, and many radiolabelled GnRH analogues were investigated and reported as well. However, there is only a little information available about fluorescently labelled GnRH analogues. GnRH peptides suitability as targeting moiety in drug delivery systems is very rarely compared and results coming out from different studies are usually not comparable. Certain cytotoxic agents such as daunorubicin have moderate fluorescence, but the emission is usually inadequate for detection and quantification at lower concentrations. The cytotoxic effect is also undesirable and disadvantageous in certain experiments. Therefore, we conclude that more precise binding and cellular uptake studies need for GnRH conjugates with higher fluorescent intensity.

The aim of our study was to investigate the synthesis of [D-Lys ${ }^{6}($ FITC)]-GnRH-I, [DLys $^{6}($ FITC) $]-G n R H-I I$ and $\left[\right.$ Lys $^{8}($ FITC)]-GnRH-III conjugates, demonstrate their usability for in vitro research, and compare their tumour targeting efficiency.

For this purpose, at first the solubility, stability, and permeability of these labelled analogues were measured. The cytotoxic effect was tested on NIH/3T3 cells. The cellular uptake was quantified by flow cytometer on the GnRH-I-R positive LNCaP, MCF-7, HT-29 and BxPC-3 tumour cells, among them on the previously not investigated Detroit-562 tumour cells, and on the GnRH-I-R negative MDCK cells. Finally the localization of the conjugates was visualised by confocal laser scanning microscopy. 


\section{Synthesis of FITC labelled GnRH Conjugates}

All GnRH analogues were synthesized manually on H-Rink Amide ChemMatrix ${ }^{\circledR}$ resin using standard Fmoc strategy. After completing the synthesis of peptides, the protecting group was selectively removed from the side chain of Lys or D-Lys. After the FITC conjugation, the conjugates were cleaved form the resins. The conjugates (Figure 1) were purified by semipreparative RP-HPLC, and characterized by HPLC-UV and ESI-MS (Table 1).

The conjugates were identified by the triply charged ions $\left([\mathrm{M}+3 \mathrm{H}]^{3+}\right)$. Tandem mass spectrometric data (fragment ions) and exact mass determination were used to confirm the structures. Based on the chromatographic data the purity of the conjugates were over $98 \%$ (Figure S1).

A

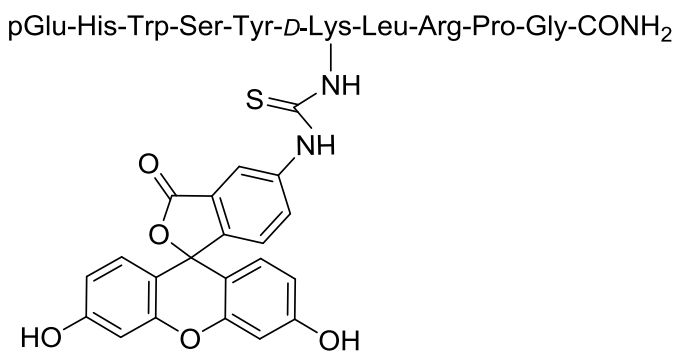

B

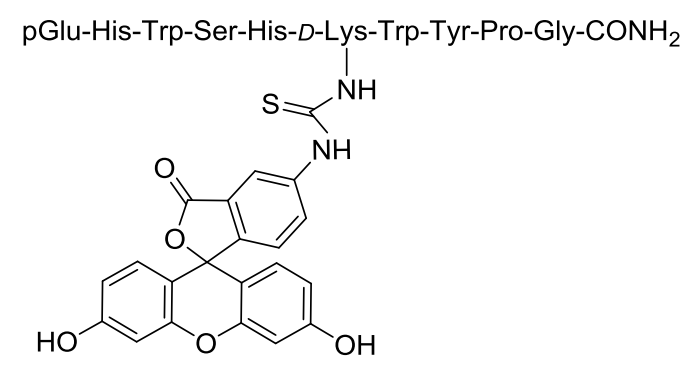

C

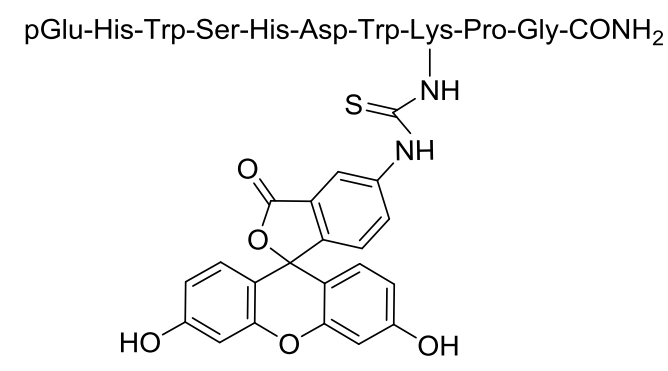


Figure 1. Schematic structures of FITC labelled GnRH-

I (A), GnRH-II (B) and GnRH-III (C) derivatives

\section{Solubility and stability evaluation of FITC-GnRH conjugates}

The solubility parameters of FITC labelled and unlabelled GnRH analogues were compared in PBS (pH: 7.4, T: $25^{\circ} \mathrm{C}$ ). Concentrations quantified by HPLC-UV (Figure S2).

We found that the unlabelled GnRH analogues dissolved readily in PBS, their solubility being over $200 \mu \mathrm{M}$. Nevertheless, it was observed that the conjugation of FITC decreased the solubility of these peptides (Table 2). The solubility of [Lys ${ }^{8}$ (FITC)]-GnRH-III remained above $200 \mu \mathrm{M}$, but the solubility of [D-Lys ${ }^{6}\left(\right.$ FITC)]-GnRH-I and [D-Lys ${ }^{6}($ FITC)]-GnRH-II decreased significantly. Precipitations could be seen as well. Based on these results, the upper concentration for all conjugates was limited to $40 \mu \mathrm{M}$ in all other experiments.

Stability of the conjugates was measured in cell culture medium (RPMI) for 24 hours at $37^{\circ} \mathrm{C}$. During the experiment the stability of all compounds was detected by RP-HPLC, no additional peak appeared, and their purity remained higher than 98\% (Figure S2).

\section{Permeability of FITC-GnRH conjugates}

Permeability across biological membranes is a key factor in the absorption and distribution of conventional drugs, but it is undesired for targeted conjugates. We tested the permeability of our conjugates by PAMPA and MDCK permeability assay.

PAMPA has become a useful tool for predicting drug permeability driven by passive transport mechanisms. We used caffeine as positive and fluorescein sodium salt as negative control. Compounds were tested at $40 \mu \mathrm{M}$ concentration, and detected by UV-VIS spectroscopy (Figure S3). We found that the conjugates and the fluorescein sodium salt had negligible permeability (Table 3). The PAMPA mass retention was the highest at [D-Lys ${ }^{6}($ FITC)]- 


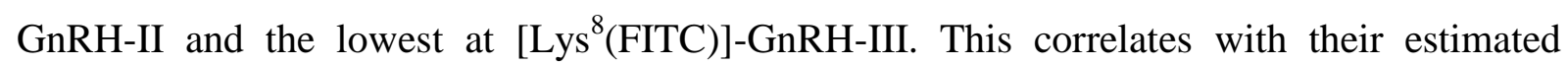
lipophilicity concluded form RP-HPLC retention times.

MDCK cell lines provide a useful tool to predict the in vivo absorption of orally administered drugs. Compounds were tested at $10 \mu \mathrm{M}$ concentration by MDCK permeability assay and detected by HPLC-UV (Figure S4). We investigated both the ,apical to basolateral”, and the „basolateral to apical” transport directions. We found that the conjugates cannot penetrate the MDCK cell monolayer, detectable peaks were not observed in the receiver chambers

After these experiments we can conclude that the FITC labelled GnRH conjugates have negligible passive permeability. This observation corroborates the presumption, that the uptake of the conjugates takes place mainly by active transport mechanisms.

\section{Cytotoxicity of FITC-GnRH conjugates}

We tested the cytotoxicity of the labelled and the unlabelled GnRH analogues on the GnRH-IR positive NIH/3T3 (mouse fibroblast) cells at $40 \mu \mathrm{M}$ concentration. Fluorescein sodium salt as negative control and staurosporin as positive control were used. It was indicated that neither the peptides nor the conjugates had significant cytotoxic effect after the 24 hours treatment (Figure 2). Thereby we suggest that these non-toxic conjugates have lower influence on the habitual behaviour of cells, which enable the reliable quantification and comparison of these GnRH analogues as targeting moieties. 


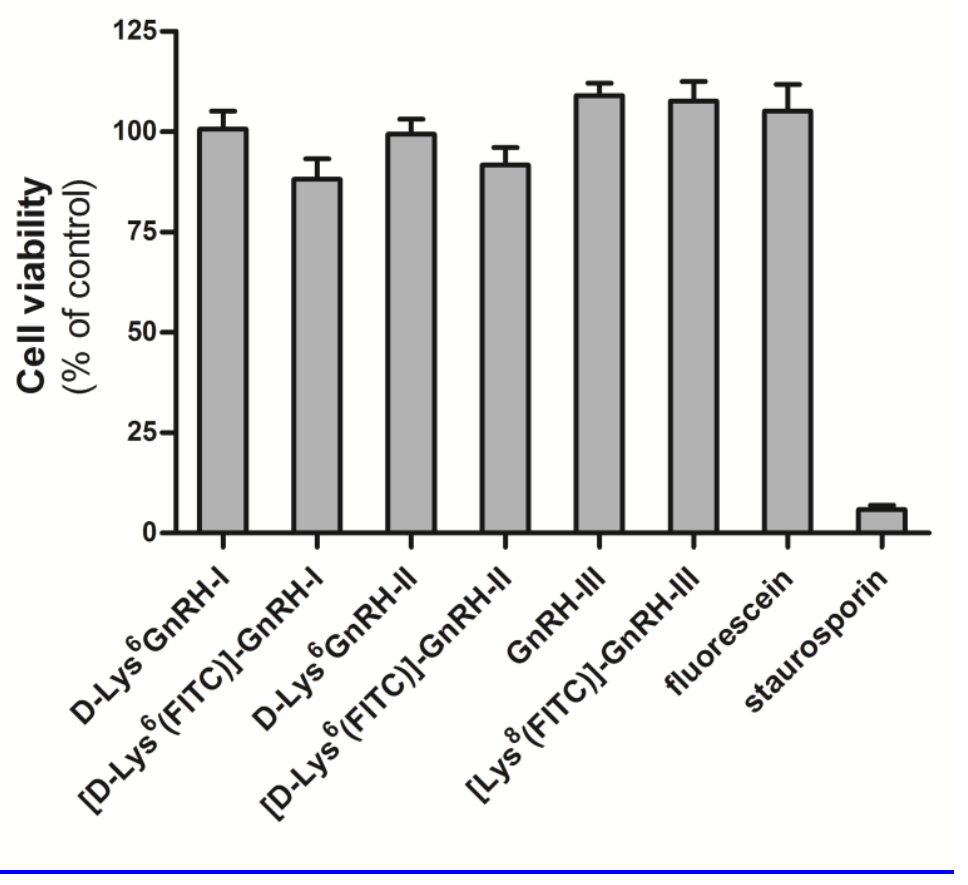

Figure 2. Cytotoxicity of the FITC labelled and the unlabelled GnRH analogues on NIH/3T3 cell line. Concentration: $40 \mu \mathrm{M}$; incubation time: $24 \mathrm{~h}$. Results were presented as $\mathrm{SD}, \mathrm{N}=3$.

\section{GnRH-I-R analysis}

The presence of GnRH-I-R has been previously demonstrated in LNCaP (prostate), MCF-7 (breast), BxPC-3 (pancreas) and HT-29 (colon) tumour cells by other groups [18,32-34]. We verified the existence of the GnRH-I-R in our corresponding cell lines, and investigated the Detroit-562 human pharynx tumour, the MDCK (dog kidney) and the NIH/3T3 (mouse fibroblast) cell lines as well (Figure 3). We used rat hypothalamus lysate as positive control. The western blot analysis revealed a clear band at approximately $38 \mathrm{kDa}$, which correspond to the predicted unmodified molecular weight of GNRH-I-R [35]. We found evidence for the presence of GnRH-I-R in the Detroit-562 and NIH/3T3 cells, however the MDCK cells do not express the human GnRH-I-R. 


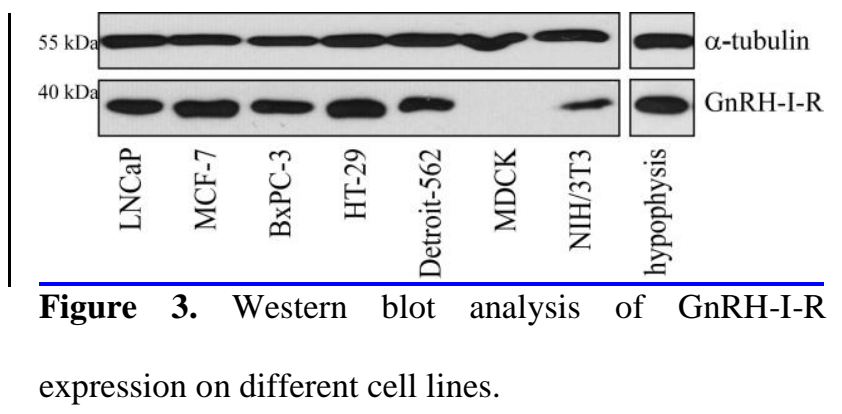

\section{Cellular uptake and cell surface GnRH-I-R analysis}

The cell surface GnRH-I-R level was investigated by immunocytochemistry. We detected varying levels of GnRH-I-R on the surface of the different, non permeabilized tumour cells. No surface GnRH-I-R was found on the non-tumoural MDCK (dog kidney) cells and only traces on the BxPC-3 (pancreas) tumour cells (Figure 4). However, permeabilized samples of BxPC-3 showed high amount of GnRH-I-R, as revealed by western blot analysis (Figure S5). This suggests that these pancreatic cells don't present GnRH-I-R on their membranes. The other tested tumour cell lines express well detectable GnRH-I-R level on their membranes (Figure 4).

Fluorescein sodium salt, the negative control, was found only in traces inside of the cells (Figure 4). This observation correlates with the permeability experiment, as fluorescein cannot penetrate cell membrane effectively without conjugation.

Experiments with our conjugates resulted that each of the three GnRH analogues were detectable inside of the cells at $10 \mu \mathrm{M}$ (Figure 4). In the same type of tumour cells the level of the three conjugates were similar and correlated with their GNRH-I-R levels. High amount of GnRH conjugates were detected in LNCaP (prostate), MCF-7 (breast) and Detroit-562 (pharynx) tumour cells, lower in HT-29 (colon) and MDCK cells, and found only traces in BxPC-3, in correlation with the results of FACS experiments. The high level of GnRH-I-R on the surface of Detroit-562 cells was associated with large quantities of GnRH conjugates in these cells (Figure 4). These results demonstrate for the first time the high cell surface 
expression of GnRH-I-R and the effective GnRH uptake on human pharynx tumour cells.

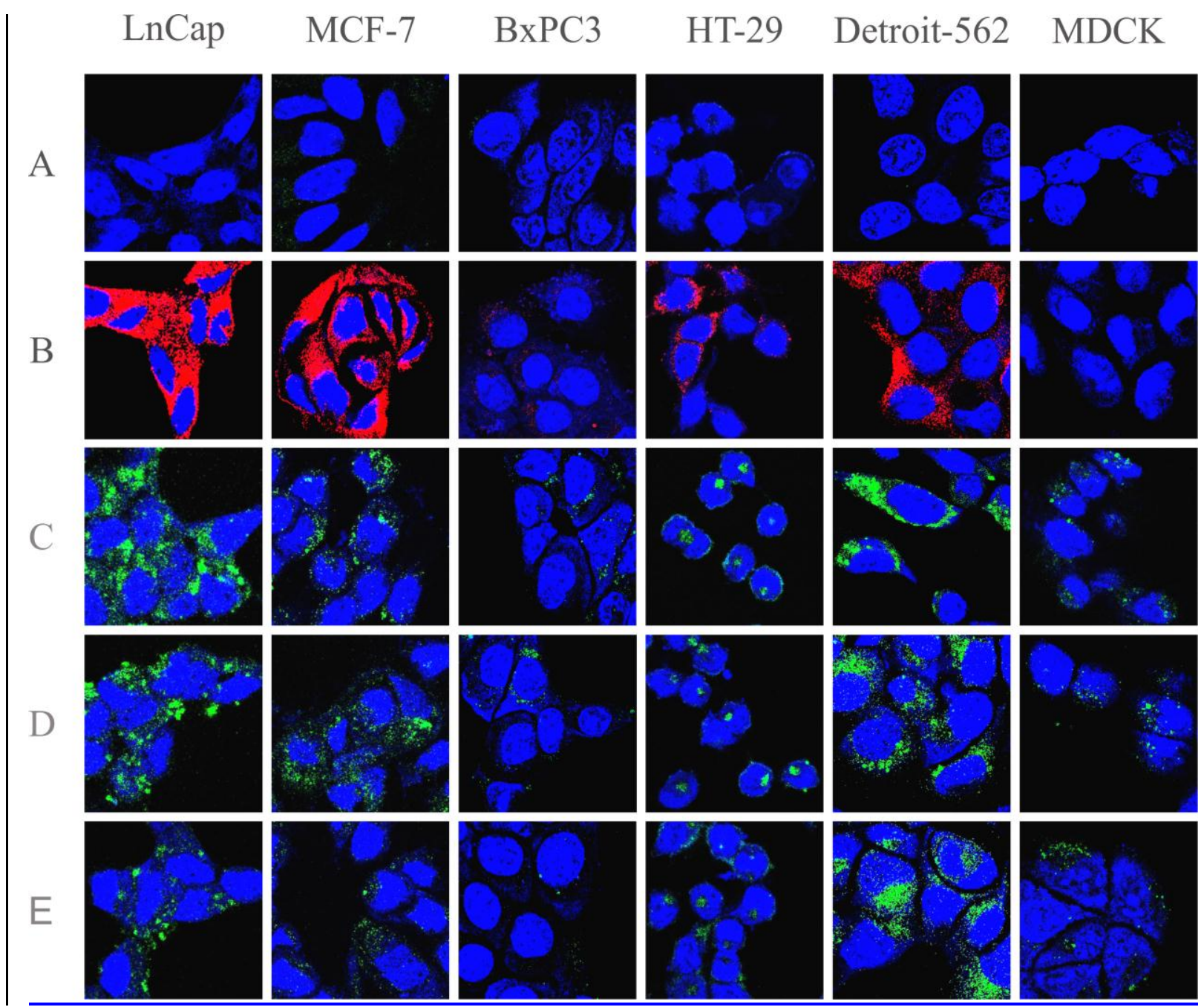

Figure 4. Confocal images of LNCaP (prostate), MCF-7 (breast), BxPC-3 (pancreas), HT-29 (colon), Detroit562 (pharynx) tumour cell lines and the MDCK (dog kidney) cell line. Treatment with fluorescein sodium salt (10 $\mu \mathrm{M})$, blue stain: nucleus, green stain: fluorescein (A). Human GnRH-I-R visualization by immunocytochemistry, blue stain: nucleus; red stain: GnRH-I-R (B). Treatment with conjugates (10 $\mu \mathrm{M})$, blue stain: nucleus; green stain: [D-Lys ${ }^{6}$ (FITC)]-GnRH-I (C); [D-Lys ${ }^{6}$ (FITC)]-GnRH-II (D); [Lys ${ }^{8}($ FITC)]-GnRH-III (E).

\section{Cellular uptake profile of FITC-GnRH conjugates}


The cellular uptake profile of GnRH conjugates was studied by flow cytometer. We found that all of the labelled GnRH analogues were detectable in each of the tested cell lines at 10 $\mu \mathrm{M}$, in correlation with the confocal microscopy experiments (Figure 5).

The LNCaP (prostate) showed the highest uptake at $10 \mu \mathrm{M}$. The MCF-7 (breast) resulted high GnRH uptake also, its efficiency was similar to the Detroit-562 (pharynx). The MDCK (dog kidney), BxPC-3 (pancreas) and HT-29 (colon) took up the conjugates moderately (Figure 5). We observed that differences between the GnRH analogues were more significant at $1 \mu \mathrm{M}$, furthermore the different cells preferred different GnRH analogues (Table 4). This observation is in context with the "selective signaling theory", which means that "GnRH receptor can assume different conformations which have different selectivity for GnRH analogs" [36]. The previously not investigated Detroit-562 cells showed the highest uptake for GnRH-I and GnRH-III at $1 \mu \mathrm{M}$ (Table 4).

Our results proved better correlation between the uptake efficiency and the surface GnRH-I-R level at $1 \mu \mathrm{M}$, than $10 \mu \mathrm{M}$ (Figure 4 and Figure 5). Significant cellular uptake was appeared for all conjugates at $10 \mu \mathrm{M}$ on the GnRH-I-R negative MDCK and on the GnRH-I-R non exhibiting BxPC-3 cells also (Figure 5). This suggests the presence of a GnRH-I-R independent uptake mechanism on these cell lines and predicts better GnRH-I-R selectivity for these conjugates below $10 \mu \mathrm{M}$. On the other hand the existence and the concentration dependent influence of the putative way is conceivable on other tested cell lines also, that should be further examined. This phenomenon correlates with the results were reported by Gründker et al. using human ovarian and endometrial cancers [18,22]. 
MDCK

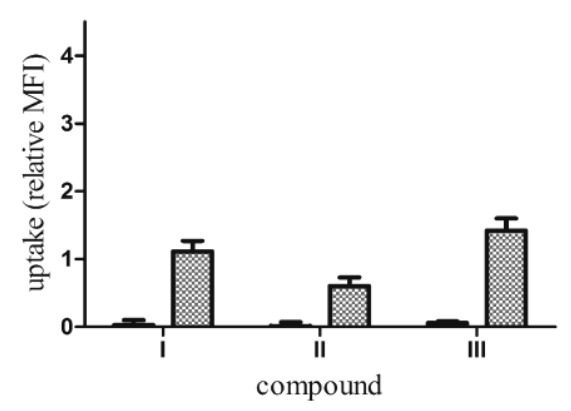

HT-29

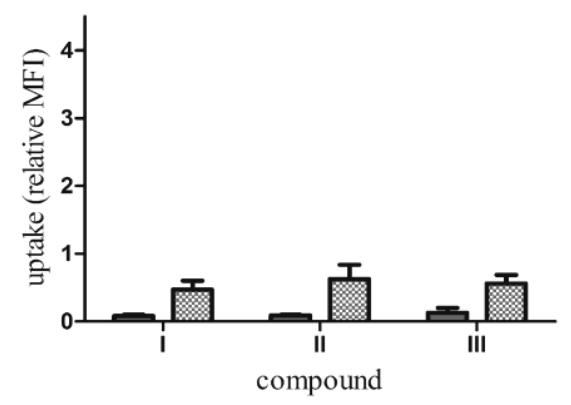

BxPC-3

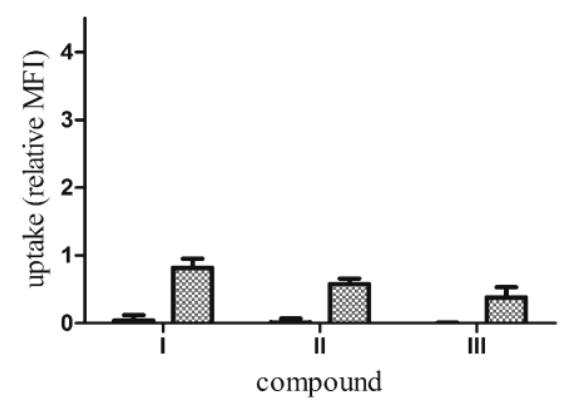

LNCaP
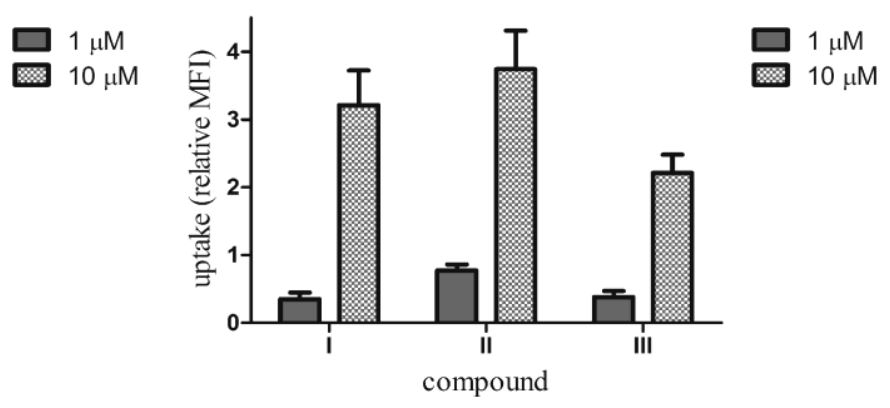

MCF-7

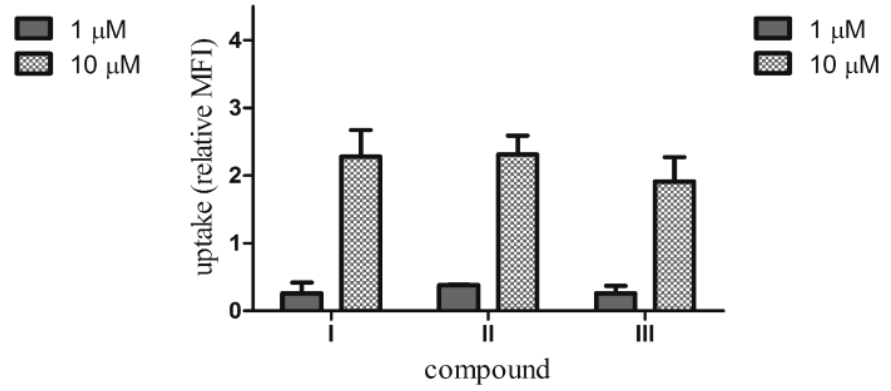

Detroit-562
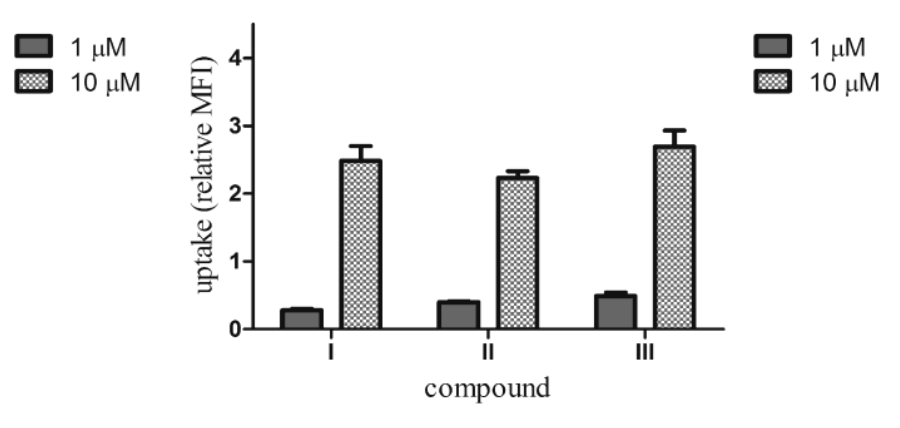

Figure 5. Uptake profile of [D-Lys ${ }^{6}\left(\right.$ FITC)]-GnRH-I (I), [D-Lys ${ }^{6}\left(\right.$ FITC)]-GnRH-II (II) and [Lys ${ }^{8}($ FITC)]-GnRHIII (III) conjugates at $1 \mu \mathrm{M}$ and $10 \mu \mathrm{M}$, between the 1 hour and 5 hours incubations. Results were presented as $\mathrm{SD}, \mathrm{N}=3$.

\section{Conclusions}

Based on our present findings we can state that these novel, selectively labelled, fluorescent GnRH derivatives are efficient tools to track and quantify their receptor mediated cellular uptake in vitro and predict the corresponding GnRH conjugates drug targeting efficiency in vivo. Experiments with these conjugates proved at first time that human pharynx tumours may also be promising targets for GnRH based therapy. 
Our results confirm that each of the three GnRH analogues are usable as drug delivery units, however different cells prefer different analogues. At the same time, we note that due to the lower endocrine activity and better solubility of GnRH-III, it might be preferable in hormone independent tumours' therapy.

We found that the effectiveness of the cellular uptake depends basically on the type of the tumour and on the applied concentration. The cellular uptake of GnRH analogues was well correlated with the level of cell surface GnRH-I-R at $1 \mu \mathrm{M}$. These results predict that these analogues have high GnRH-I-R selectivity below $1 \mu \mathrm{M}$. Furthermore, we suppose that the uptake of these GnRH peptides could take place not only by the human GnRH-I receptors, especially at higher concentrations $(10 \mu \mathrm{M}$ or above), but this unknown active transport mechanism should be further examined.

\section{Acknowledgements}

The project was supported by National Research Fund OTKA (K 104045).

\section{References}

1 Siegel RL, Miller KD, Jemal A. Cancer Statistics, 2016. CA. Cancer J. Clin. 2016; 66: $7-$ 30; DOI:10.3322/caac. 21332.

2 Schally AV, Comaru-Schally AM, Nagy A, Kovacs M, Szepeshazi K, Plonowski A, Varga JL, Halmos G. Hypothalamic Hormones and Cancer. Front. Neuroendocrinol. 2001; 22: 248-291; DOI:10.1006/frne.2001.0217.

3 Hierowski MT, Altamirano P, Redding TW, Schally AV. The Presence of LHRH-like Receptors in Dunning R3327H Prostate Tumors. FEBS Lett 1983; 154: 92-96.

4 Eidne KA, Flanagan CA, Millar RP. Gonadotropin-Releasing Hormone Binding Sites in Human Breast Carcinoma. Science 1985; 229: 989-991.

5 Montagnani Marelli M, Moretti RM, Januszkiewicz-Caulier J, Motta M, Limonta P. Gonadotropin-Releasing Hormone (GnRH) Receptors in Tumors: A New Rationale for the Therapeutical Application of GnRH Analogs in Cancer Patients? Curr Cancer Drug Targets 2006; 6: 257-269.

6 Schally AV, Nagy A. Chemotherapy Targeted to Cancers through Tumoral Hormone Receptors. Trends Endocrinol Metab 2004; 15: 300-310; DOI:10.1016/j.tem.2004.07.002.

7 Nagy A, Schally AV. Targeting of Cytotoxic Luteinizing Hormone-Releasing Hormone Analogs to Breast, Ovarian, Endometrial, and Prostate Cancers. Biol Reprod 2005; 73: 851-859; DOI:10.1095/biolreprod.105.043489. 
8 Schally AV, Nagy A. Cancer Chemotherapy Based on Targeting of Cytotoxic Peptide Conjugates to Their Receptors on Tumors. Eur J Endocrinol 1999; 141: 1-14.

9 Harrison GS, Wierman ME, Nett TM, Glode LM. Gonadotropin-Releasing Hormone and Its Receptor in Normal and Malignant Cells. Endocr Relat Cancer 2004; 11: 725-748; DOI:10.1677/erc.1.00777.

10Labrie F, Dupont A, Bélanger A, St-Arnaud R, Giguère M, Lacourcière Y, Emond J, Monfette G. Treatment of Prostate Cancer with Gonadotropin-Releasing Hormone Agonists. Endocr Rev 1986; 7: 67-74.

11Dondi D, Limonta P, Moretti RM, Marelli MM, Garattini E, Motta M. Antiproliferative Effects of Luteinizing Hormone-Releasing Hormone (LHRH) Agonists on Human Androgen-Independent Prostate Cancer Cell Line DU 145: Evidence for an AutocrineInhibitory LHRH Loop. Cancer Res 1994; 54: 4091-4095.

12 Grundker C, Gunthert AR, Westphalen S, Emons G. Biology of the GonadotropinReleasing Hormone System in Gynecological Cancers. Eur J Endocrinol 2002; 146: 1-14. 13 Millar RP. GnRHs and GnRH Receptors. Anim. Reprod. Sci. 2005; 88: 5-28; DOI:10.1016/j.anireprosci.2005.05.032.

14Limonta P, Dondi D, Moretti RM, Maggi R, Motta M. Antiproliferative Effects of Luteinizing Hormone-Releasing Hormone Agonists on the Human Prostatic Cancer Cell Line LNCaP. J Clin Endocrinol Metab 1992; 75: 207-212; DOI:10.1210/jcem.75.1.1320049.

15 Janáky T, Juhász A, Bajusz S, Csernus V, Srkalovic G, Bokser L, Milovanovic S, Redding TW, Rékási Z, Nagy A, Schally AV. Analogues of Luteinizing Hormone-Releasing Hormone Containing Cytotoxic Groups. Proc Natl Acad Sci U A 1992; 89: 972-976.

16 Miyamoto K, Hasegawa Y, Nomura M, Igarashi M, Kangawa K, Matsuo H. Identification of the Second Gonadotropin-Releasing Hormone in Chicken Hypothalamus: Evidence That Gonadotropin Secretion Is Probably Controlled by Two Distinct Gonadotropin-Releasing Hormones in Avian Species. Proc Natl Acad Sci U A 1984; 81: 3874-3878.

17 White RB, Eisen JA, Kasten TL, Fernald RD. Second Gene for Gonadotropin-Releasing Hormone in Humans. Proc Natl Acad Sci U A 1998; 95: 305-309.

18 Gründker C, Föst C, Fister S, Nolte N, Günthert AR, Emons G. Gonadotropin-Releasing Hormone Type II Antagonist Induces Apoptosis in MCF-7 and Triple-Negative MDA-MB231 Human Breast Cancer Cells in Vitro and in Vivo. Breast Cancer Res. 2010; 12; DOI: $10.1186 /$ bcr2606.

19Fister S, Gunthert AR, Aicher B, Paulini KW, Emons G, Grundker C. GnRH-II Antagonists Induce Apoptosis in Human Endometrial, Ovarian, and Breast Cancer Cells via Activation of Stress-Induced MAPKs p38 and JNK and Proapoptotic Protein Bax. Cancer Res 2009; 69: 6473-6481; DOI:10.1158/0008-5472.can-08-4657.

20Montagnani Marelli M, Moretti RM, Mai S, Januszkiewicz-Caulier J, Motta M, Limonta P. Type I Gonadotropin-Releasing Hormone Receptor Mediates the Antiproliferative Effects of GnRH-II on Prostate Cancer Cells. J Clin Endocrinol Metab 2009; 94: 1761-1767; DOI:10.1210/jc.2008-1741.

21 Grundker C, Gunthert AR, Millar RP, Emons G. Expression of Gonadotropin-Releasing Hormone II (GnRH-II) Receptor in Human Endometrial and Ovarian Cancer Cells and Effects of GnRH-II on Tumor Cell Proliferation. J Clin Endocrinol Metab 2002; 87: 14271430; DOI:10.1210/jcem.87.3.8437.

22 Grundker C, Schlotawa L, Viereck V, Eicke N, Horst A, Kairies B, Emons G. Antiproliferative Effects of the GnRH Antagonist Cetrorelix and of GnRH-II on Human Endometrial and Ovarian Cancer Cells Are Not Mediated through the GnRH Type I Receptor. Eur J Endocrinol 2004; 151: 141-149. 
23 Szabó I, Bosze S, Orbán E, Sipos E, Halmos G, Kovács M, Mezo G. Comparative in Vitro Biological Evaluation of Daunorubicin Containing GnRH-I and GnRH-II Conjugates Developed for Tumor Targeting. J. Pept. Sci. 2015; DOI:10.1002/psc.2775.

24 Sower SA, Chiang YC, Lovas S, Conlon JM. Primary Structure and Biological Activity of a Third Gonadotropin-Releasing Hormone from Lamprey Brain. Endocrinology 1992; 132: $1125-1131$.

25 Lovas S, Palyi I, Vincze B, Horvath J, Kovacs M, Mezo I, Toth G, Teplan I, Murphy RF. Direct Anticancer Activity of Gonadotropin-Releasing Hormone-III. J Pept Res 1998; 52: 384-389.

26Mezo I. Synthesis of Gonadotropin-Releasing Hormone III Analogs. Structure- Antitumor Activity Relationships. J. Med. Chem. 1997; 40: 3353-3358; DOI:10.1021/jm9700981.

27 Schreier VN, Petho L, Orbán E, Marquardt A, Petre BA, Mezo G, Manea M. Protein Expression Profile of HT-29 Human Colon Cancer Cells after Treatment with a Cytotoxic Daunorubicin-GnRH-III Derivative Bioconjugate. PLoS One 2014; 9;

DOI:10.1371/journal.pone.0094041.

28 Montagnani Marelli M, Manea M, Moretti RM, Marzagalli M, Limonta P. Oxime BondLinked Daunorubicin-GnRH-III Bioconjugates Exert Antitumor Activity in CastrationResistant Prostate Cancer Cells via the Type I GnRH Receptor. Int J Oncol 2015; 46: 243253; DOI:10.3892/ijo.2014.2730.

29Manea M, Tóvári J, Tejeda M, Schulcz Á, Kapuvári B, Vincze B, Mezo G. In-Vivo Antitumour Effect of Daunorubicin-GnRH-III Derivative Conjugates on Colon CarcinomaBearing Mice. Anticancer Drugs 2012; 23: 90-97; DOI:10.1097/CAD.0b013e32834bb6b4. 30 Matsuo H, Baba Y, Nair RM, Arimura A, Schally AV. Structure of the Porcine LH- and FSH-Releasing Hormone. I. The Proposed Amino Acid Sequence. Biochem Biophys Res Commun 1971; 43: 1334-1339.

31 Dong-Ki K, Ji SY, Kaushik M, Jong-Ik H, Kyungjin K, Dongseung S, Younghee A, Cheolji L, Byeong-Cheol K, Hyuk BK, Jun C, Jae YS. A Gonadotropin-Releasing Hormone-II Antagonist Induces Autophagy of Prostate Cancer Cells. Cancer Res 2009; 69: 923-931; DOI:10.1158/0008-5472.CAN-08-2115.

32 Mezo G, Czajlik A, Manea M, Jakab A, Farkas V, Majer Z, Vass E, Bodor A, Kapuvari B, Boldizsar M, Vincze B, Csuka O, Kovacs M, Przybylski M, Perczel A, Hudecz F. Structure, Enzymatic Stability and Antitumor Activity of Sea Lamprey GnRH-III and Its Dimer Derivatives. Peptides 2007; 28: 806-820; DOI:10.1016/j.peptides.2006.12.014.

33 Aggarwal S, Ndinguri MW, Solipuram R, Wakamatsu N, Hammer RP, Ingram D, Hansel W. [DLys(6)]-Luteinizing Hormone Releasing Hormone-Curcumin Conjugate Inhibits Pancreatic Cancer Cell Growth in Vitro and in Vivo. Int J Cancer 2011; 129: 1611-1623; DOI:10.1002/ijc.26132.

34Limonta P, Moretti RM, Marelli MM, Dondi D, Parenti M, Motta M. The Luteinizing Hormone-Releasing Hormone Receptor in Human Prostate Cancer Cells: Messenger Ribonucleic Acid Expression, Molecular Size, and Signal Transduction Pathway.

Endocrinology 1999; 140: 5250-5256; DOI:10.1210/endo.140.11.7087.

35URL: http://www.ptglab.com/Products/GNRHR-Antibody-19950-1-AP.htm 36 Millar RP, Pawson AJ, Morgan K, Rissman EF, Lu Z-L. Diversity of Actions of GnRHs Mediated by Ligand-Induced Selective Signaling. Front. Neuroendocrinol. 2008; 29: 17 35; DOI:http://dx.doi.org/10.1016/j.yfrne.2007.06.002.

\section{Supporting Information}


Additional Supporting Information may be found in the online version of this article at the publisher's web site. 
Table 1. Chromatographic and mass spectrometric data of [D-Lys ${ }^{6}$ (FITC)]-GnRH-I, [D-Lys ${ }^{6}$ (FITC)]GnRH-II and $\left[\right.$ Lys $^{8}($ FITC)]-GnRH-III

\begin{tabular}{|c|c|c|c|c|}
\hline \multirow[b]{2}{*}{ compound name } & \multirow{2}{*}{$\begin{array}{c}\text { RP-HPLC } \\
t_{R}(\min )\end{array}$} & \multicolumn{3}{|c|}{ ESI-MS $^{b}$} \\
\hline & & {$[\mathrm{M}+3 \mathrm{H}]^{3+}$ calc } & {$[\mathrm{M}+3 \mathrm{H}]^{3+} \exp$} & $\mathrm{MW}_{\text {exact }}$ \\
\hline [D-Lys $\left.^{6}(\mathrm{FITC})\right]-\mathrm{GnRH}-\mathrm{I}$ & 9.83 & 548.23 & 548.23 & 1641.68 \\
\hline$\left[\mathrm{D}^{-\mathrm{Lys}^{6}}{ }^{6}(\mathrm{FITC})\right]-\mathrm{GnRH}-\mathrm{II}$ & 10.12 & 566.21 & 566.21 & 1695.64 \\
\hline$\left[\mathrm{Lys}^{8}(\mathrm{FITC})\right]-\mathrm{GnRH}-\mathrm{III}$ & 9.52 & 550.20 & 550.20 & 1647.60 \\
\hline \multicolumn{5}{|c|}{$\begin{array}{l}{ }^{\text {a }} \text { Column: Technokroma }{ }^{\circledR} \text { Mediterranea Sea C18 column (50 mm x } 4.0 \mathrm{~mm}, 3 \mu \mathrm{m} \text { ); gradient: } 0 \text { min } \\
0 \% \mathrm{~B}, 12 \min 50 \% \mathrm{~B} ; 12.1 \mathrm{~min} 90 \% \mathrm{~B} \text { and } 14 \mathrm{~min} 90 \% \mathrm{~B} \text {; eluents: } 0.1 \% \text { TFA in water (A) and } \\
\text { acetonitrile (B), flow rate: } 1 \mathrm{~mL} / \mathrm{min} \text {; detection: } \lambda=220 \mathrm{~nm} \\
{ }^{\mathrm{b}} \text { Molecular weight determination by Waters Q-TOF Premier Mass Spectrometer }\end{array}$} \\
\hline
\end{tabular}




\begin{tabular}{|c|c|c|}
\hline \multirow[t]{2}{*}{ compound } & \multicolumn{2}{|c|}{ solubility $^{\mathbf{a}}$} \\
\hline & $\mu \mathrm{M}$ & $\mathrm{mg} / \mathrm{mL}$ \\
\hline D-Lys ${ }^{6}-\mathrm{GnRH}-\mathrm{I}$ & $>200$ & $>0,25$ \\
\hline [D-Lys $^{6}($ FITC)]-GnRH-I & $94 \pm 7$ & 0,15 \\
\hline D-Lys ${ }^{6}-\mathrm{GnRH}-\mathrm{II}$ & $>200$ & $>0,26$ \\
\hline D-Lys $^{6}($ FITC $\left.)\right]-G n R H-I I$ & $48 \pm 3$ & 0,08 \\
\hline GnRH-III & $>200$ & $>0,25$ \\
\hline [Lys $^{8}($ FITC)]-GnRH-III & $>200$ & $>0,33$ \\
\hline \multicolumn{3}{|c|}{$\begin{array}{l}\text { a solvent: PBS; } \mathrm{pH}: 7.4 \text {; temperature: } 25^{\circ} \mathrm{C} \text {; upper limit } \\
\text { of quantification: } 200 \mu \mathrm{M} \text {; results were presented as } \mathrm{SD} \text {, } \\
\mathrm{N}=4\end{array}$} \\
\hline
\end{tabular}


Table 3. Permeability of [D-Lys ${ }^{6}\left(\right.$ FITC)]-GnRH-I, [D-Lys ${ }^{6}\left(\right.$ FITC)]-GnRH-II and [Lys ${ }^{8}($ FITC)]GnRH-III

\begin{tabular}{|c|c|c|}
\hline compound & $\operatorname{Pe}(n m / s)^{a}$ & $\mathbf{R}(\%)^{b}$ \\
\hline [D-Lys $^{6}($ FITC)]-GnRH-I & $\sim 0.0$ & 23.7 \\
\hline$\left[\mathrm{D}^{-\mathrm{Lys}^{6}}{ }^{6}(\mathrm{FITC})\right]-\mathrm{GnRH}-\mathrm{II}$ & $\sim 0.0$ & 35.1 \\
\hline$\left[\operatorname{Lys}^{8}(\mathrm{FITC})\right]-\mathrm{GnRH}-\mathrm{III}$ & $\sim 0.0$ & 14.5 \\
\hline fluorescein sodium salt & $0.2 \pm 0.1$ & 7.8 \\
\hline caffeine & $19.9 \pm 0.9$ & $\sim 0.0$ \\
\hline \multicolumn{3}{|c|}{$\begin{array}{l}{ }^{\mathrm{a}} \text { Pe: Permeability (nm/s); results were presented as } \mathrm{SD}, \mathrm{N}=2 \\
\text { burfaces during the permeation assay) }\end{array}$} \\
\hline
\end{tabular}


Table 4. Total uptake of [D-Lys ${ }^{6}\left(\right.$ FITC)]-GnRH-I (I), [D-Lys ${ }^{6}$ (FITC)]-GnRH-II (II) and [Lys ${ }^{8}($ FITC)]-GnRHIII (III)

\begin{tabular}{|c|c|c|c|c|c|c|}
\hline \multirow[t]{2}{*}{ cell line } & \multicolumn{2}{|c|}{$\begin{array}{c}\left.\text { [D-Lys }{ }^{6}(\mathrm{FITC})\right]- \\
\text { GnRH-I* }\end{array}$} & \multicolumn{2}{|c|}{$\begin{array}{c}\left.\text { [D-Lys }{ }^{6}(\mathrm{FITC})\right]- \\
\text { GnRH-II* }\end{array}$} & \multicolumn{2}{|c|}{$\begin{array}{c}\left.\text { Lys }^{8}(\mathrm{FITC})\right]- \\
\text { GnRH-III* }\end{array}$} \\
\hline & 1 hour & 5 hours & 1 hour & 5 hours & 1 hour & 5 hours \\
\hline MDCK & $0.08 \pm 0.06$ & $0.11 \pm 0.02$ & $0.04 \pm 0.06$ & $0.05 \pm 0.01$ & $0.09 \pm 0.03$ & $0.15 \pm 0.02$ \\
\hline LNCaP & $0.20 \pm 0.05$ & $0.56 \pm 0.10$ & $0.34 \pm 0.03$ & $1.11 \pm 0.05$ & $0.16 \pm 0.02$ & $0.54 \pm 0.08$ \\
\hline MCF-7 & $0.31 \pm 0.10$ & $0.57 \pm 0.08$ & $0.35 \pm 0.13$ & $0.73 \pm 0.14$ & $0.24 \pm 0.08$ & $0.50 \pm 0.07$ \\
\hline BxPC-3 & $0.14 \pm 0.09$ & $0.09 \pm 0.05$ & $0.05 \pm 0.05$ & $0.07 \pm 0.01$ & $0.03 \pm 0.04$ & $0.01 \pm 0.02$ \\
\hline НТ-29 & $0.10 \pm 0.05$ & $0.19 \pm 0.07$ & $0.12 \pm 0.06$ & $0.21 \pm 0.05$ & $0.17 \pm 0.02$ & $0.30 \pm 0.07$ \\
\hline Detroit-562 & $0.32 \pm 0.02$ & $0.61 \pm 0.03$ & $0.27 \pm 0.04$ & $0.67 \pm 0.03$ & $0.33 \pm 0.05$ & $0.82 \pm 0.08$ \\
\hline
\end{tabular}

